\title{
KEMAMPUAN BACA AI-QURAN SIS WA SMP DIKABUPATEN GOWA
}

\author{
Oleh: Pat Badrun
}

\begin{abstract}
This research was conducted in Gowa, South Sulawesi. Especially at SMPN 1 Sungguminasa, SMPN 3 Sungguminasa, and SMPN 4 Sungguminasa. This research aims to describe the student ability on reading Al-Qur'an andfactors influence that ability. This uses quantitative method, where data was collected by questioner. Then, data was analyzed by statistical analysis.

This research indicates that ability degree on reading Al-Qur'an of those students of the three schools is commonly good enough. This good ability was influenced by several factors, are (a) local tradition assumes that ability on reading the Al-Qur'an is an obligatory;(b) the application of government regulation no. 07/2003 about "free from Quranic script less ", especially to all elementary and junior high school students; (c) the school regulation that makes the student prepare themselves on reading Al-Qur'an. This good ability, than, influenced by prejuniorhigh school education, method in reading and writing Al-Qur'an, and the student motivation.
\end{abstract}

Key words: ability, reading, Al-Qur'an, student

\section{PENDAHULUAN}

B

erkenaan dengan kemampuan membaca Al-Qur'an dalam kurikulum pendidikan agama Islam tahun 1994 tujuan pembelajaran AlQur'an sebagai salah satu unsurpokok bidang studi pendidikan agama Islam padajenjang pendidikan menengah pada (SMP dan SMA), siswa dituntut memiliki 4 (empat) kemampuan yaitu: (1) Fasih membaca surat-surat Al-Qur'an pilihan, 2) Menyalinnya dengan baik, 3) Mengartikan dengan benar dan 4) Menjelaskan isi kandungannya. Berkaitan dengan kemampuan membaca ayatayat Al-Qur'an dijelaskan lebih lanjut yaitu, benar bacaannya. baik dan lancar dalam melaksanakannya, tepat dan sesuai dari segi makhraj dan ilmu tajwidnya. 


\section{Pat Badrun}

serta benar dalam menyambung kata-kata (mufradat kalimat)nya (Ditjen PembinaanKelembagaanAgama Islam, 1999/2000:73). Dalam kurikulum 2004 dijelaskan bahwa kompetensi-kompetensi Dasar UntukAspekAl-Qur' an diukur dengan indikator siswa dapat: 1). Membaca dengan fasih; 2) Menjelaskan penerapan ilmu tajwid dan 3) Menyimpulkan kandungan surat-surat Al-Qur'an (Syamsuri, Pendidikan Agama Islam, 2005 viii). Dengan demikian maka kemampuan siswa dalam belajar Al-Qur'an penekanannya mulai dari caracara membaca menurut tajwid sampai kepada menerapkan pada hukum-hukum bacaan mad dan wakaf serta kefasihan dalam membacanya.

Meskipun improvisasi di bidang metodologi sekaligus mencuatkan semangat optimisme baru bagi masyarakat untuk kembali menengok kemandekan pembelajaran Al-Qur'an selama ini dan pemerintah sendiri, membuat program-program remedial lewat sekolah dasar dan menengah melalui program dan bebas buta aksara AlQur'an dan gerakan pembelajaran Al-Qur'an (GPQ), namun dewasa ini masih banyak orang mempertanyakan keberhasilan pendidikan agama di sekolah. Salah satu indikasinya adalah kenyataan peserta didik setelah belajar 12 tahun (SD). umumnya masih banyak tidak mampu membaca Al-Qur'an dengan baik.

Berkenaan dengan kemampuan baca Al-Qur'an siswa Sekolah Menengah (SMP) Balai Penelitian dan Pengembangan Agama Makassar tahun 1996 pernah melakukan penelitian di 6 (enam) Kodya/Kabupaten di Propinsi Sulawesi Selatan pada 12 SMP Negeri dan 5 SMP Swasta. Hasil penelitian tersebut antara lain bahwa kemampuan membaca Al-Qur'an para Siswa sebagai responden di setiap kabupaten di Propinsi Sulawesi Selatan secara umum dikategorikan mampu membaca dengan lancar $42,0 \%$, kurang lancar 40,7 \%, sangat lancar $8,30 \%$ dan tidak dapat membaca 9,0\%. Pada setiap kabupaten responden yang mampu membaca dengan baik dan fasih serta memahami ilmu tajwid jumlahnya masih kecil, berkisar pada $9,0 \%-10,0 \%$.

Penelitian kemampuan membaca Al-Qur'an yang telah dilakukan oleh Balai Penelitian dan Pengembangan Agama Makassar ini sudah berlangsung 10 tahun yang lalu dengan cakupan wilayah hanya di 6 kabupaten di Sulawesi Selatan, dan hasil monitoring dan evaluasi Tim Pemantau Gerakan Pembelajaran AlQur'an se Propinsi Sulawesi Selatan tahun 2004 menyatakan bahwa secara umum Gerakan Pembelajaran Al-Qur'an di Sulawesi Selatan belum berjalan secara efektip. Oleh karena itu dengan tenggang waktu yang sudah lama dan terbatasnya cakupan wilayah penelitian yang dilakukan Balai Penelitian dan

Pengembangan Agama Makassar dan hasil evaluasi Gerakan Pembelajaran 


\section{Pat Badrun}

Al-Qur'an menyatakan belum efektip maka dipandang perlu untuk melakukan penelitian kemampuan baca Al-Qur'an untuk mengetahui gambaran kemampuan membaca Al-Qur'an siswa SMP sekarang ini.

Pendidikan dan pengajaran Al-Qur'an memperoleh perhatian yang meningkat, baik dari masyarakat maupun dari pemerintah beberapa tahun terakhir ini, pendidikan tersebut bukan hanya pada pendidikan n'on formal, akan tetapi juga pada pendidikan formal. Usaha ini diharapkan memberikan hasil secara meluas dengan meningkatkan kemampuan baca Al-Qur'an bagi masyarakat Islam terutama bagi anak-anak, remaja dan siswa. Bahkan pada gilirannya nanti tidak hanya meningkatkan kemampuan baca Al-Quran tetapi juga kemampuan untuk mengartikan dan menjelaskan isi/kandungan ayat-ayat Al-Qur'an. Berdasarkan uraian diatas maka masalah pokok penelitian ini adalah:

1. Bagaimana tingkat kemampuan membaca Al-Qur'an siswa SMP?

2. Faktor-faktor apa yang berpengaruh terhadap kemampuan membaca Al-Qur'an siswa SMP.

\section{METODE PENELITIAN}

\section{Pendekatan}

Penelitian ini akan dilakukan dengan menggunakan pendekatan kuantitatif. Penerapan pendekatan kuantitatif terutama dalam penyimpulan data yang berbentuk skor dan dalam sistem analisis data dengan analisis statistik baik statistik deskriptif maupun statistik infrensian. Statistik deskriptif digunakan untuk menggambarkan data tentang tingkat kemampuan membaca siswa SMP yang menjadi sasaran penelitian. Disamping itu juga untuk menggambarkan data terkait dengan faktor-faktor yang digunakan berpengaruh terhadap kemampuan membaca Al-Qur'an.

\section{Populasi dan Sampel}

Populasi dari penelitian ini adalah siswa SMP di Kabupaten Gowa. Sedangkan populasi terjangkau adalah siswa kelas dua pada SMP di lokasi penelitian. Ditetapkan siswa kelas dua sebagai sasaran penelitian dengan pertimbangan pelajaran membaca Alquran sebagai salah satu komponen bidang studi PA1 sebagai muatan kurikulum telah diterima oleh siswa SMP selama belajar di kelas satu dan dua berdasarkan kurikulum 1994 atau kurikulum KBK tahun 2004 dan kurikulum KTSP tahun 2006.. 


\section{Pat Badrun}

Sampel dari populasi yang diteliti pada setiap wilayah di pilih tiga sekolah SMP dengan mewakili sekolah yang dianggap paporit, menengah dan kurang. Dalam penelitian di Kabupaten Gowa, tiga SMP Negeri yang dipilih, masingmasing SMP Negeri I Sungguminasa, SMP Negeri III Sungguminasa, dan SMP Negeri IV Sungguminasa. Ketiganya berada dalam wilayah Kecamatan Sumbaopu. Siswa kelas II yang dipilih secara acak dari setiap sekolah dijadikan responden penelitian ini.

3. Teknik Pengumpulan Data

Pengumpulan data dalam penelitian ini dilakukan teknik:

a. Angket, yaitu daftar pertanyaan yang diberikan kepada responden untuk diisi sendiri.

b. Tes, dilakukan secara langsung oleh peneliti untuk mengetahui tingkat kemampuan baca Al-Qur'an responden.

c. Wawancara mendalam, dilakukan peneliti terhadap para informan dengan berpedoman kepada pedoman wawancara agar tidak mengambang

d. Observasi, dengan mengamati kondisi kehidupan beragama masyarakat dan tempat-tempat pengajian Al-Qur' an, di lingkungan di mana sekolah berada serta kondisi lingkungan sekolah.

e. Studi dokumen dan perpustakaan, untuk melihat data tertulis yang berkaitan dengan penelitian.

4. Pengolahan dan Analisa Data

a. Pengolahan data. Pengolahan data dilakukan sesuai dengan prosedur yang lazim dengan memperhitungkan bentuk dan sifat data yang terkumpul. Data hasil/jawaban kuesioner yang berbentuk data individu diolah dan ditampilkan dalam bentuk table frekwesni. Hasil tes prestasi membaca Al-Qur'an dihitung dengan menjumlahkan skor setiapdimensi dari setiap responden kemudian dikatagorikan menjadi 4 tingkatan kemampuan membaca Al-Qur' an lalu dilakukan perhitungan nilai skor setiap responden kemudian disusun dalam table daftar nilai skor setiap variable.

b. Analisis data. Setelah tahap-tahap pengelolaan data dilakukan maka dilanjutkan dengan analisis data dengan menerapkan analisis statistik deskriptif dan analisis statistik infrensial. Analisis statistik deskriptif 
dilakukan dalam bentuk table frekwensi kemudian diberi verbalisasi dan interpretasi yang relevan. Analisis statistik infrensial dilakukan dengan menerapkam Analisis Statistik Varian (Anava) Satu Jalur, pada taraf signifikansi alpha 0.05 dengan batuan piranti lunak SPSS. Anava Satu Jalur dilakukan untuk menguji hipotesis yang diajukan mengenai faktor-faktor yang mempengaruhi kemampuan membaca Al-Quran siswa.

\section{TEMUAN DAN PEMBAHASAN}

\section{A. Kemampuan Membaca Alquran Siswa}

Data tentang kemampuan membaca Alquran siswa, diperoleh lewat jawaban-jawaban siswa terhadap pertanyaan yang diajukan dalam kuesioner dan lewat hasil tes prestasi membaca Alquran siswa yang dilakukan oleh peneliti. Dalam tulisan ini, kemampuan pertama di atas disebut kemampuan umum membaca Alquran dan kemampuan kedua disebut kemampuan khusus membaca Alquran.

1. Kemampuan Umum Membaca Alquran

Ada 4 (empat) aspek kemampuan umum membaca Alquran siswa yang diamati dalam penelitian ini, yakni: (1) kemampuan membaca hurufhijaiyah dengan berbagai harakat, (2) kemampuan membaca Alquran dengan dasar tajwid, (3) kemampuan membaca Alquran dengan benar dan fasih, serta

(4) kemampuan membaca surah-surah dalam Alquran.

a. Kemampuan membaca huruf hijaiyah berharakat

Tampak (tabel 1) berikut bahwa sebagian besar (76\% lebih) responden dari tiga sekolah yang diteliti menyatakan diri memiliki kemampuan membaca huruf hijaiyah dengan berbagai harakat. Selebihnya menyatakan diri kurang mampu. Bila dirinci menurut sekolah atau kelompok siswa/responden maka lebih $89 \%$ responden siswa SMP Negeri 1 Sungguminasa menyatakan diri memiliki kemampuan membaca huruf hijaiyah berharakat, $62 \%$ responden siswa SMP Negeri 3 Sungguminasa, dan $77 \%$ responden siswa SMP Negeri 4 Sungguminasa menyatakan diri memiliki kemampuan yang sama. 


\section{Pat Badrun}

Tabel 1

Distribusi Frekuensi Siswa Menurut Kemampuan Mereka Membaca Huruf Hijaiyah Berharakat untuk Tiga Kelompok Siswa yang diteliti di Kabupaten Gowa

\begin{tabular}{|c|c|c|c|c|c|c|c|}
\hline No. & \multirow{2}{*}{ Kelompok Siswa } & \multicolumn{5}{|c|}{ Kemampuan Membaca Alquran } & \multirow{2}{*}{$\mathrm{K}$ et } \\
\hline Urut & & SM & $M$ & $\mathrm{KM}$ & TM & Juml & \\
\hline \multirow[t]{2}{*}{1} & SMP Negeri 1 & - & 33 & 4 & - & 37 & \\
\hline & Sungguminasa & & & & & & \\
\hline \multirow[t]{2}{*}{2} & SMP Negeri 3 & 1 & 21 & 12 & - & 34 & \\
\hline & Sungguminasa & & & & & & \\
\hline \multirow[t]{3}{*}{3} & SMP Negeri 4 & - & 30 & 9 & - & 39 & \\
\hline & Sungguminasa & & & & & & \\
\hline & Jumlah & 1 & 84 & 25 & - & 110 & \\
\hline
\end{tabular}

b. Kemampuan membaca Alquran dengan dasar tajwid

Tabel 2.

Distribusi Frekuensi Responden menurut Kemampuan Mereka Membaca Alquran dengan Dasar Tajwid untuk Tiga Kelompok Siswa yang diteliti di Kabupaten Gowa.

\begin{tabular}{|c|c|c|c|c|c|c|c|}
\hline No. & \multirow{2}{*}{ Kelompok Siswa } & \multicolumn{5}{|c|}{ Kemampuan Membaca Alquran } & \multirow{2}{*}{$\mathrm{K}$ et } \\
\hline Urut & & SM & $M$ & KM & TM & Juml & \\
\hline \multirow[t]{2}{*}{1} & SMP Negeri 1 & - & 11 & 22 & 4 & 37 & \\
\hline & Sungguminasa & & & & & & \\
\hline \multirow[t]{2}{*}{2} & SMP Negeri 3 & 1 & 5 & 26 & 2 & 34 & \\
\hline & Sungguminasa & & & & & & \\
\hline \multirow[t]{3}{*}{3} & SMP Negeri 4 & 1 & 14 & 24 & - & 39 & \\
\hline & Sungguminasa & & & & & & \\
\hline & Jumlah & 2 & 30 & 72 & 6 & 110 & \\
\hline
\end{tabular}

Data pada Tabel 2 di atas menunjukkan bahwa lebih separuh $(65,45 \%)$ responden dari tiga sekolah yang diteliti menyatakan diri memiliki kemampuan membaca Alquran dengan dasar tajwid, malah terdapat 6 (enam) responden $(5,45 \%)$ yang menyatakan diri tidak mampu. Selebihnya yakni $27 \%$ lebih responden menyatakan diri mampu, bahkan $1,82 \%$ yang menyatakan diri sangat mampu. Bila diamati menurut kelompok siswa, lebih 59\% responden siswa SMP Negeri 1, lebih 76 $\%$ responden siswa SMP Negeri 3, dan lebih $61 \%$ responden siswa 
SMP Negeri 4 yang menyatakan diri kurang mampu membaca Alquran dengan dasar tajwid. Responden siswa SMP Negeri 4, sebanyak $35,90 \%$ yang menyatakan diri memiliki kemampuan, disusul responden siswa SMP Negeri 1 sebanyak $29,73 \%$, dan responden siswa SMP Negeri 3 sebanyak 14,7\%. Bahkan terdapat sebanyak 10,8\% respondenSMP Negeri 1 dan 5,88\% responden siswa SMP Negeri 3 yang menyatakan diri tidak mampu membaca Alquran dengan dasar tajwid.

c. Kemampuan membaca Alquran dengan benar dan fasih.

Tabel 3.

Distribusi Frekuensi Responden menurut Kemampuan Mereka Membaca Alquran dengan Benar dan Fasih untuk

Tiga Kelompok Siswa yang diteliti di Kabupaten Gowa.

\begin{tabular}{|c|c|c|c|c|c|c|c|}
\hline No. & \multirow{2}{*}{ Kelompok Siswa } & \multicolumn{5}{|c|}{ Kemampuan Membaca Alquran } & \multirow{2}{*}{ Ket } \\
\hline Urut & & SM & $\mathrm{M}$ & KM & TM & Juml & \\
\hline \multirow[t]{2}{*}{1} & SMP Negeri 1 & & 26 & 11 & - & 37 & \\
\hline & Sungguminasa & & & & & & \\
\hline \multirow[t]{2}{*}{2} & SMP Negeri 3 & - & 12 & 22 & - & 34 & \\
\hline & Sungguminasa & & & & & & \\
\hline \multirow[t]{3}{*}{3} & SMP Negeri 4 & 1 & 23 & 15 & - & 39 & \\
\hline & Sungguminasa & & & & & & \\
\hline & Jumlah & 1 & 61 & 48 & - & 110 & \\
\hline
\end{tabular}

Dari sejumlah 110 resporlden untuk tiga sekolah yang diteliti ternyata lebih separuh $(55,45 \%)$ yang mengaku memiliki kemampuan membaca Alquran dengan benar dan fasih, dan sisanya yakni lebih $44 \%$ mengaku kurang mampu. Hal ini terungkap lewat data Pada Tabel 3 di atas. Bila dirinci menurut kelompok siswa, lebih $70 \%$ responden siswa SMP Negeri 1 Sungguminasa yang mengaku mampu dan selebihnya mengaku kurang mampu. Sebaliknya responden siswa SMP Negeri 3 Sungguminasa, lebih $35 \%$ yang mengaku mampu sedangkan selebihnya mengaku tidak mampu. Responden siswa SMP Negeri 4 Sungguminasa, 58,97\% diantaranya mengaku mampu dan selebihnya mengaku kurang mampu. 


\section{Pat Badrun}

d. Kemampuan membaca surah-surah dalam Alquran

\section{Tabel 4.}

Distribusi Frekuensi Responden menurut Kemampuan Mereka Membaca Surah-surah Alquran untuk Tiga Kelompok Siswa yang diteliti di Kabupaten Gowa.

\begin{tabular}{|c|c|c|c|c|c|c|c|}
\hline No. & \multirow{2}{*}{ Kelompok Siswa } & \multicolumn{5}{|c|}{ Kemampuan Membaca Alquran } & \multirow{2}{*}{$\mathrm{K}$ et } \\
\hline Urut & & $\mathrm{M}($ & $\mathrm{M}_{2}$ & $\mathrm{M}_{3}$ & $\mathrm{M}_{4}$ & Juml & \\
\hline \multirow[t]{2}{*}{1} & SMP Negeri 1 & 32 & 1 & 4 & - & 37 & \\
\hline & Sungguminasa & & & & & & \\
\hline \multirow[t]{2}{*}{2} & SMP Negeri 3 & 2 & 5 & 7 & 20 & 34 & \\
\hline & Sungguminasa & & & & & & \\
\hline \multirow[t]{3}{*}{3} & SMP Negeri 4 & 19 & - & 4 & 16 & 39 & \\
\hline & Sungguminasa & & & & & & \\
\hline & Jumlah & 1 & 61 & 48 & - & 110 & \\
\hline
\end{tabular}

Catatan:

$\boldsymbol{M}_{i}$ : mampu membaca surah-surah pendek Juz Amma $\mathrm{M}_{2}$ : mampu membaca beberapa surah panjang Juz Amma

$\mathbf{M}_{3}$ : mampu membaca semua surah Juz Amma

$\mathrm{M}_{4}$ : mampu membaca beberapa surah panjang Alquran

Hampir separuh $(48,18 \%)$ responden dari tiga sekolah yang diteliti mengaku mampu membaca beberapa surah panjang dalam Alquran, lebih 5\% yang mengaku hanya mampu membaca semua surah dalam Juz Amma, lebih $13 \%$ yang mengaku hanya mampu membaca beberapa surah panjang dalam Juz Amma, dan lebih 32\% yang mengaku hanya mampu membaca surah-surah pendek dalam Juz Amma. Bila diamati menurut kelompok siswa, sebagian besar $(86,49 \%)$ responden siswa SMP Negeri 1 Sungguminasa yang mengaku mampu membaca beberapa surah panjang dalam Alquran, selebihnya mengaku hanya mampu membaca beberapa surah panjang dalam Juz Amma. Sebaliknya lebih separuh $(58,82 \%)$ responden siswa SMP Negeri 3 Sungguminasa mengaku hanya mampu membaca surah-surah pendek yang terdapat dalam Juz Amma, lebih 20\% yang mengaku mampu membaca surah-surah panjang dalam Juz Amma, dan selebihnya mengaku mampu membaca semua surah dalam Juz Amma diantaranya lebih 5\% yang mengaku mampu membaca beberapa surah yang tidak terlalu panjang dalam Alquran. 


\section{Pat Badrun}

Responden siswa SMP Negeri 4 Sungguminasa, hampir sebanding jumlahnya yang mengaku mampu membaca semua surah dalam Alquran dengan jumlah yang mengaku hanya mampu membaca surahsurah pendek dalam Juz Amma (masing-masing berjumlah 48,72\% dan $51,28 \%)$. Uraian yang dikemukakan di atas, dapat dilihat datanya pada Tabel 4 di atas.

2. Kemampuan Khusus Membaca Alquran Siswa

Data hasil penelitian tentang kemampuan khusus membaca Alquran siswa diperoleh melalui hasil tes prestasi membaca Alquran siswa/responden yang diteliti. Skor total yang diperoleh setiap siswa adalah jumlah skor setiap dimensi tes. Skor total tersebut kemudian dikategorikan menjadi tiga katergori tingkatan kemampuan membaca Alquran siswa, masing-masing dengan rentang skor yang diperoleh siswa/responden setiap kelompok atau setiap sekolah. Dengan demikian, kelompok siswa SMP Negeri 1 Sungguminasa yang memiliki total skor dengan rentangan dari 77 sampai 100 (artinya skor terendah siswa adalah 77 dan skor tertinggi 100), kategori I terdiri dari 77 sampai 84, kategori II dari 85 sampai 92-, dan kategori III dari 93 sampai 1000.

Responden SMP Negeri 3 Sugguminasa yang memiliki total skor dengan rentangan dari 58 sampai 100, kategori I terdiri dari 58 sampai 72, katergori II dari 73 sampai 86, dan kategori III dari 87 sampai 100. Adapun responden SMP Negeri 4 Sungguminasa yang memiliki total skor dengan rentangan dari 69 sampai 100, kategori I dari 69 sampai 79, kategori II dari 80 sampai 90, dan kategori III dari 91 sampai 100.

Perlu dijelaskan bahwa sesungguhnya rentangan nilai skor yang diperoleh setiap kelompok siswa/responden berada dalam kategori mampu. Karena itu kategori yang diberikan itu dapat ditafsirkan sebagai berikut:

- Kategori I dapat diartikan sebagai tingkat kemampuan dasar;

- Kategori II dapat diartikan sebagai tingkat kemampuan sedang;

- Kategori III dapat diartikan sebagai tingkat kemampuan optimal.

Distribusi data skor dari kategorisasi tingkat kemampuan khusus membaca Alquran siswa dari tiga kelompok responden dapat dilihat pada Tabel 5 di bawah ini. 
Tabel 5.

Distribusi dan Kategorisasi Skor Kemampuan Khusus Membaca Alquran Siswa dari Tiga Kelompok Siswa yang diteliti di Kabupaten Gowa Tahun 2007

\begin{tabular}{|c|c|c|c|c|c|c|}
\hline \multirow{2}{*}{$\begin{array}{l}\text { No. } \\
\text { Urut }\end{array}$} & \multirow{2}{*}{ Kelompok Siswa } & \multicolumn{4}{|c|}{ Kemampuan Membaca Alquran } & \multirow[t]{2}{*}{ Ket } \\
\hline & & $\mathbf{I} /(\mathbf{R})$ & III/(R) & III/(R) & TS/(R) & \\
\hline \multirow[t]{2}{*}{1} & SMP Negeri 1 & $77-84$ & $85-92$ & $93-100$ & 3486 & I/II/III/:Kategori \\
\hline & Sungguminasa & ( 0 ) & ' (13) & - (21) & $(37)$ & \\
\hline \multirow[t]{2}{*}{2} & SMP Negeri 3 & $58-72$ & $73-86$ & $87-100$ & 3046 & TS : Total Skor \\
\hline & Sungguminasa & ' (D) & ( 0 ) & - (24) & (34) & \\
\hline \multirow[t]{4}{*}{3} & SMP Negeri 4 & $69-79$ & $80-90$ & $91-100$ & 3741 & R: Responden \\
\hline & Sungguminasa & . (2) & ( $\quad(6)$ & ' $\quad(3 D$ & - (39) & \\
\hline & Jumlah & - (6) & - (28) & - (76) & $\cdot(110)$ & \\
\hline & & $5,45 \%$ & $25,46 \%$ & $69,09 \mathrm{k} / \mathrm{k}$ & & \\
\hline
\end{tabular}

Tampak jelas pada Tabel 5 di atas bahwa sebagian besar $(69,09 \%)$ responden penelitian memiliki tingkat kemampuan membaca Alquran kategori III yakni tingkat kemampuan optimal. Kategori II (tingkat kemampuan sedang) 25,46\%, dan kategori I (tingkat kemampuan dasar) sebanyak 5,45\%. Bila dirinci menurut kelompok siswa/responden, keadaannya memiliki kecenderungan yang sama, yakni sebagian besar responden dari masing-masing kelompok memiliki tingkat kemampuan membaca Alquran kategori III, disusul kemudian dengan kategori II dan kategori I. Total skor untuk masing-masing kelompok siswa atau sekolah adalah 3486 untuk 37 responden SMP Negeri 1 Sungguminasa, 3046 untuk 34 responden SMP Negeri 3 Sungguminasa, dan 3741 untuk 39 responden SMP Negeri 4 Sungguminasa. 
3. Perbandingan Kemampuan Khusus MernbaeafAlquran Siswa antara Tiga Kelompok Siswa (Tiga SMP Negeri) yang diteliti.

\section{Tabel 6.}

Perbandingan Kemampuan Khusus Membaca Alquran Siswa antara Tiga Kelompok Siswa yang diteliti di Kabupaten Gowa, Tahun 2007.

\begin{tabular}{|c|l|c|c|c|c|}
\hline No. & \multirow{2}{*}{ Kelompok Siswa } & \multirow{2}{*}{$\mathbf{N}$} & Total & Rerata & \multirow{2}{*}{ Ke t } \\
\cline { 1 - 3 } Urut & & Skor & Skor & \multirow{2}{*}{} \\
\hline 1 & SMP Negeri 1 & 37 & 3486 & 94,21622 & \\
\hline & Sungguminasa & & & & \\
\hline 2 & SMP Negeri 3 & 34 & 3046. & 89,58824 & \\
\hline & Sungguminasa & & & & \\
\hline 3 & SMP Negeri 4 & 39 & 3741 & 95,92308 & \\
\hline & Sungguminasa & & & & \\
\hline & Jumlah & 110 & 10273 & 93,39 & \\
\hline
\end{tabular}

Berdasarkan data tersebut pada Tabel 6 di atas, dilakukan analisis perbandingan dengan teknis analisis statistik inferensial analisis (anava) satu jalur atau One Way Analysis of Varieance (Anova) pada taraf signifikan $5 \%$ atau alfa 0,05 dengan bantuan piranti lunakSPSS.

\section{B. Ual-hal yang Mempengaruhi Kemampuan Membaca Alquran Siswa}

Seperti dikemukakan bagian hipotesis bahwa ada 15 hal yang diduga mempengaruhi kemampuan membaca Alquran siswa. Hal-hal yang dimaksud meliputi pendidikan sebelum SMP, usia belajar, tempat belajar, guru yang mengajar, metode yang digunakan motivasi, lama belajar, kendala belajar, minat belajar, intelegensi, pendengaran, penglihatan, pengucapan, dan sikap terhadap sanksi hukum. Melalui uji statistik Anova (Anava) diperoleh hasil yang menunjukkan orientasi atau kecenderungan pengaruh tersebut. Berikut ditampilkan hasil uji yang dimaksud.

1. Pendidikan siswa sebelum SMP

Dari sejumlah 110 responden penelitian, 108 orang atau 98,18\% diantaranya berpendidikan SD sebelum masuk SMP, selebihnya berpendidikan Diniyah 1 orang dan Ibtidaiyah 1 orang.

Perbandingan sekolah asal sebelum SMP dari siswa yang diteliti tersebut di atas bila dikaitkan dengan hasil tes langsung kemampuan membaca 


\section{Pat Badrun}

Hasil penelitian menunjukkan bahwa metode Iqra' merupakan metode yang paling banyak digunakan responden, (104 dari 110 responden menggunakannya). Selebihnya menggunakan metode Bagdadiyah da metode Qira'ati. Dominasi penggunaan metode Iqra' (94,545\%) tampaknya mempengaruhi kemampuan membaca Alquran siswa.

\section{Motivasi}

Bermacam-macam motif atau alasan yang mendorong responden untuk balajar membaca Alquran, antara lain karena disuruh orang tua, kemauan sendiri, kewajiban sebagai seorang Islam, untuk mendukung pelajaran agama di sekolah, dan karena dorongan teman. Namun alasan terbanyak ialah untuk memenuhi kewajiban sebagai seorang Islam (90 dari 110 responden atau $81,818 \%)$, disusul alasan kemauan sendiri $(15,454 \%)$, karena dorongan orang tua $(1,82 \%)$ dan karena keperluan mendukung pelajaran agama di sekolah $(0,909 \%)$.

Keragaman motif tersebut, tetapi masih didominasi oleh motif tertentu yakni untuk memenuhi kewajiban sebagai seorang Islam, Tampaknya memberikan pengaruh yang signifikan terhadap kemampuan membaca Alquran siswa.

8. Lama belajar

Dari 110 responden penelitian, 53 diantaranya $(48,18 \%)$ yang belajar sampai setengah jam/hari ketika belajar mengaji. Selebihnya, 27 responden $(24,545 \%)$ yang hanya mampu bertahan belajar selama kurang dari satu jam/hari. Responden yang mampu belajar sampai dua jam per hari sebanyak 30 (27,27\%).

Variasi lama belajar responden setiap hari seperti ditampilkan lewat hasil penelitian ini, tampaknya tidak mempengaruhi kemampuan membaca Alquran siswa.

9. Kendala belajar

Kemampuan membaca Alquran siswa semula diduga dipengaruhi oleh berbagai kendala seperti kurang minat, cacat fisik, kurang buku pegangan, kurang waktu, cara mengajar guru yang kurang menarik, dan sulitnya belajar membaca Alquran. Data hasil penelitian menunjukkan bahwa 73 dari 110 responden $(66,36 \%)$ yang terkendala karena kurang waktu, 17 responden atau $15,454 \%$ yang terkendala karena kurang buku, 8 (delapan) responden atau 7,27\% yang terkendala soal cara guru mengajar yang kurang menarik, 7 (tujuh) responden karena kurang minat dan 1 (satu) responden karena cacat fisik. 


\section{Pat Badrun}

10. Minat belajar

Kemampuan membaca Alquran sedikit banyak berkaitan dengan minat belajar. Dalam penelitian ini diperoleh informasi bahwa 108 dari 110 responden $(98,18 \%)$ memiliki minat belajar yang cukup besar untuk mempelajari/ mengetahui membaca Alquran dengan baik; bahkan lebih 40\% diantaranya yang memiliki minat belajar yang sangat besar. Kecenderungan dominasi ini tampaknya tidak mempengaruhi kemampuan membaca Alquran siswa.

11. Intelegensi

Diasumsikan bahwa persepsi siswa mengenai mudah tidaknya belajar Alquran merupakan manifestasi dari intelegensi siswa. Dalam penelitian ini ditemukan bahwa $60 \%$ responden menganggap belajar membaca Alquran itu bukan hal yang sulit atau mudah, sedangkan selebihnya menganggap tidak begitu mudah.

\section{Pendengaran}

Hasil penelitian menginformasikan bahwa seluruh responden yang berjumlah 110 itu menyatakan dapat mendengar ucapan/perkataan guru ketika mengikuti pelajaran membaca Alquran yang diajarkan guru mengaji mereka; bahkan ada 77 atau 70,90\% responden yang menyatakan mendengar dengan jelas, 10 responden yang menyatakan sangat jelas, dan 23 atau $20,91 \%$ responden yang menyatakan cukup jelas.

Variasi pernyataan responden mengenai kejelasan pendengaran itu tampaknya tidak berpengaruh terhadap kemampuan membaca Alquran siswa.

13. Penglihatan

Faktor penglihatan, dalam arti kejelasan penglihatan, oleh sebagian orang dirasakan berpengaruh terhadap kemampuan membaca Alquran, walaupun tidak jarang disaksikan orang yang tuna netra mampu membaca lancar Alquran. Dalam penelitian ini hampir seluruh responden (108 atau 98,18\%) menyatakan dapat melihat dan mengenai huruf dan tulisan Alquran yang diajarkan guru ketika belajar mengaji, diantaranya 71 responden atau $64,54 \%$ yang menyatakan terang, 30 responden atau 27,27\% menyatakan sangat terang, dan 8 (delapan) responden atau $7,27 \%$ menyatakan cukup terang. Ketika pernyataan mereka itu dihubungkan dengan prestasi hasil tes dalam sistem analisis Anava satu jalur, tampaknya perbedaan kualitas penglihatan responden tersebut tidak berpengaruh terhadap kemampuan membaca Alquran siswa. 


\section{Pat Badrun}

\section{Pengucapan}

Lebih separuh $(50,91 \%)$ responden menyatakan memiliki pengucapan yang sempurna dan selebihnya kurang sempurna dalam membaca huruf dan perkataan dalam Alquran. Kesempurnaan pengucapan selain karena faktor pengetahuan yang terbatas juga karena faktor fisik yakni cacat alat pengucapan. Dalam penelitian ini, perbedaan kulaitas pengucapan responden tampaknya tidak berpengaruh terhadap kemampuan Alquran siswa.

15. Sikap terhadap sanksi hukum

Hampir seluruh responden penelitian (104 atau 94,55\%) yang menyetujui pemberian semacam sanksi kepada siswa (beragama Islam) yang tidak dapat atau tidak tahu membaca Alquran, dan hanya 6 (enam) responden $(5,45 \%)$ yang tidak menyetujui pemberian sanksi tersebut.

Perlu ditambahkan di sini bahwa sanksi hukum itu dimaksudkan untuk menunjukkan kedisiplinan siswa belajar membaca Alquran. Responden yang setuju adanya sanksi dipersepsikan sebagai siswa yang disiplin sedangkan mereka yang tidak menyetujui adanya sanksi dipersepsikan sebagai siswa yang tidak disiplin.

\section{PEMBAHASAN}

Hasil analisis yang ditampilkan pada Bab II kelihatannya masih sangat teknis dan karena itu perlu dilakukan komentar dan/atau pembahasan mengenai beberapa hal agar lebih jelas dan lebih bermakna.

\section{A. Kemampuan Membaca Alquran Siswa}

Data pokok mengenai kemampuan membaca Alquran siswa, dalam penelitian ini, diperoleh lewat dua cara atau teknik. Cara pertama diperoleh lewat kuesioner yang diedarkan kepada seluruh siswa yang menjadi responden penelitian, dan cara kedua diperoleh lewat tes langsung prestasi kemampuan membaca Alquran dari masing-masing responden. Karena itu data yang diperoleh itu dikelompokkan menjadi dua macam dengan penamaan yang sedikit berbeda. Data yang diperoleh lewat kuesioner disebut data tentang kemampuan umum membaca Alquran siswa, Sedangkan data yang diperoleh sebagai hasil tes langsung disebut data tentang kemampuan kliusus membaca Alquran siswa.

Memperhatikan kecenderungan kedua kelompok data tersebut, ternyata bahwa data tentang kemampuan umum membaca Alquran siswa relatif lebih 


\section{Pat Badrun}

bervariasi menurut kategori tingkat kemampuan yang diberikan 4 (empat) kategori yakni sangat mampu, mampu, kurang mampu, dan tidak mampu, sementara data tentang kemampuan khusus membaca Alquran siswa relatif homogen dan terpusat pada kategori mampu.

Salah satu pemahaman serta interpretasi yang dapat diangkat dari fenomena ini ialah bahwa materi pelajaran membaca Alquran yang diperoleh siswa di sekolah dipandang lebih rendah tingkat kesulitannya (dipandang lebih mudah) oleh siswa dari pada materi pembelajaran membaca Alquran yang diikuti siswa di masyarakat. Hal ini perlu mendapat perhatian, terutama oleh pihak yang berkompeten dalam proses penyusunan kurikulum mata pelajaran agama Islam (PAI) di sekolah umum. karena sedikit banyak menyangkut citra pendidikan formal.

Hal ini memungkinkan anak-anak usia SD ke bawah pada umumnya di lokasi penelitian sudah mampu membaca Alquran, adalah tradisi masyarakat umat Islam di daerah ini yang memandang kemampuan membaca Alquran anak sejak dini (sejak usia SD ke bawah) sebagai suatu keharusan adat. Seorang anak yang sudah melampaui usia SD tapi belum juga "tamat mengaji" atau belum tahu membaca Alquran biasa mendapat ejekan sebagai "kurang beradat". Karena itu pula menjadikan sang anak "tahu mengaji" adalah menjadi tanggungan atau kewajiban orang tua.

Tradisi tahu mengaji sebagai bagian dari keharusan adat, sering dikaitkan dengan citra diri "orang Gowa" yang menurut sejarah tercatat sebagai komunitas pertama menerima agama Islam di wilayah Sulawesi Selatan dengan nama besar seorang tokoh keturunan raja pertama penerima agama Islam secara resmi di Sulawesi Selatan (Sultan Alauddin) yakni Syekh Syusuf yang juga tercatat sebagai pahlawan nasional. Penduduk asli wilayah Kecamatan Somba Opu lokasi tempat berdomisili tiga SMP Negeri yang siswanya dijadikan responden penelitian ini banyak yang mengaku keturunan dari Syekh Yusuf, setidaknya mengaku rumpun keluarga dari keturunan Syekh Yusuf.

Sejak tahun 2003, seorang anak muslim warga Kabupaten Gowa yang telah menyelesaikan studinya di tingkat SD, bila ingin melanjutkan studinya ke tingkat SMP/SLTPharus mengantongi persyaratan tambahan selain tanda lulus dan/atau ijazah SD. Persyaratan tambahan yang dimaksudkan ialah sertifikat/ijazah khusus sebagai bukti yang bersangkutan "bebas buta aksara Alquran". Bahkan persyaratan itu diberlakukan pula terhadap siswa SD yang akan mengikuti ujian akhir SD atau Madrasah Ibtidaiyah. Ketentuan mengenai hal ini diatur di dalam Peraturan Daerah (Perda) Kabupaten Gowa Nomor 07 Tahun 2003 dan mulai 
diberlakukan Januari 2003. Tiga SMP Negeri tempat pelaksanaan penelitian ini telah memberlakukan dengan tegas peraturan daerah tersebut, antara lain tidak sekedar melihat sertifikat yang dimiliki calon siswa tetapi juga melakukan pengetesan langsung mengenai kemampuannya membaca Alquran.

Menurut keterangan dari kepala sekolah ketiga SMP Negeri yang diteliti, dalam penerapan Perda Nomor 03 Tahun 2007 Kabupaten Gowa tersebut, terkadang ditemukan kejanggalan, seperti antara lain ada calon siswa yang mengantongi sertifikat bebas buta aksara Alquran tetapi ketika dilakukan pengetesan langsung ternyata yang bersangkutan belum tahu sama sekali membaca Alquran. Namun pada akhirnya bila persyaratan lain terpenuhi yang bersangkutan dapat diterima dengan syarat membuat pernyataan kesiapan untuk dibina khusus yang disetujui orang tua calon siswa bersangkutan.

Hal lain yang turut memacu kemampuan membaca Alquran siswa SMP Negeri yang diteliti ialah adanya kebijaksanaan dari ketiga sekolah untuk memanfaatkan peluang "pengembangan diri" yang ada dalam kurikulum dengan mengadakan salah satu kegiatan ekstra kulikuler yang bersifat keagamaan yakni kegiatan "kultum". Kegiatan ini dapat diikuti oleh semua jenjang kelas secara bergilir dengan sistem perwakilan kelompok. Menurut keterangan dari beberapa orang siswa yang diwawancarai bahwa kegiatan ini cukup memacu kegiatan siswa untuk tidak hanya mampu membaca Alquran tetapi lebih dari itu mampu mengetahui arti dan isi kandungan Alquran itu sendiri. Hampir setiap siswa memiliki buku terjemahan Alquran, terbanyak Buku Tarjamah Alquran terbitan Departemen Agama R. I.

\section{B. Faktor-faktor yang Mempengaruhi Kemampuan Membaca Alquran Siswa.}

Semula diduga ada banyak hal yang mempengaruhi kemampuan membaca Alquran siswa yang dalam penelitian ini dihipotesiskan ada 15 hal. Penentuan 15 hal yang diduga sebagai faktor-faktor yang dapat mempengaruhi kemampuan membaca Alquran siswa, di samping dengan alasan logis juga berdasarkan informasi hasil-hasil peneltian sebelumnya dengan topik dan masalah yang sama atau hampir sama.

Kelima belas faktor tersebut di atas dapat dikelompokkan menjadi dua kelompok, yakni pertama, faktor-faktor eksternal dan $\boldsymbol{k} \boldsymbol{e d u a}$, faktor-faktor internal. Termasuk faktor-faktor eksternal adalah, pendidikan sebelum SMP, usia ketika mulai belajar membaca Alquran atau mengaji, tempat belajar mengaji, 


\section{Pat Badrun}

guru yang mengajar mengaji, buku pegangan yang digunakan belajar mengaji, metode belajar mengaji yang dipraktekkan guru, motif/alasan yang mendorong belajar mengaji, lama belajar mengaji setiap hari, dan kendala yang dihadapi (siswa) ketika belajar mengaji. Sedangkan yang termasuk faktqr-faktor internal adalah minat belajar membaca Alquran dari siswa bersangkutan, intelegensi siswa, pendengaran siswa, penglihatan siswa, pengucapan siswa, dan kedisiplinan siswa.

Dari 15 faktor yang semula dihipotesiskan sebagai faktor-faktor yang mempengaruhi kemampuan membaca Alquran siswa, setelah dilakukan penelitian (pengumpulan data, pengolahan, analisis data, dan uji hipotesis)ternyata hanya 5 (lima) faktor yang terbukti memberikan pengaruh yang signifikan. Ke-lima faktor itu ialah pendidikan siswa sebelum SMP, buku pegangan yang digunakan belajar mengaji, metode belajar mengaji yang dipraktekkan guru, moti vasi/alasan yang mendorong siswa belajar mengaji, dan pengucapan siswa. Jadi tiga faktor eksternal dan satu faktor internal.

Kelima faktor yang berpengaruh itu dapat dijelaskan lebih lanjut sebagai berikut:

1. Pendidikan Siswa Sebelum SMP.

Data hasil penelitian menginformasikan bahwa hampir seluruh (104 atau $98,18 \%$ ) responden peneliti ini yang berjumlah 110 orang, berpendidikan SD dan selebihnya 2 (dua) orang berpendidikan Madrasah Ibtidaiyah.

Di dalam wilayah Kecamatan Somba Opu (wilayah lokasi penelitian dengan ibu kota Sungguminasa yang juga wilayah ibu kota Kabupaten Gowa) terdapat 44 SD dan sebuah Madrasah Ibtidaiyah. Untuk melanjutkan studi di tingkat SLTP, para siswa tamatan SD dapat mendaftarkan diri pada sejumlah 14 buah SLTPdalam wilayah kecamatan ini, termasuk4 SMP Negeri. Tiga diantaranya merupakan lokasi sampel sasaran penelitian ini. SMP Negeri I Sungguminasa berada di pusat kota lama, SMP Negeri IV Sungguminasa berada di kawasan perluasan kota, dan SMP Negeri III Sungguminasa berada di pinggir kota Sungguminasa. Dengan demikian banyaknya siswa SD yang melanjutkan studi pada 3 SMP Negeri yang diteliti merupakan hal yang wajar dan proporsional. Perbedaan Sekolah asal sebelum SMP (yang didominasi oleh SD Umum), bila dikaitkan dengan hasil tes langsung siswa (dengan analisis statistik Anava satu jalur) ternyata berpengaruh terhadap kemampuan membaca Alquran siswa.

2. Buku pegangan yang digunakan belajar mengaji

Di lokasi penelitian, setidaknya ada tiga macam buku yang lazim digunakan anak ketika baru memulai belajar mengaji, yakni Buku Juz Amma, Buku 
Iqra', dan buku yang disiapkan di sekolah-sekolah. Hasil penelitian ini menginformasikan bahwa buku pegangan mengaji yang paling banyak digunakan siswa ketika mulai belajar mengaji ialah Buku Iqra'. Lebih seratus, tepatnya 104 dari 110 responden (94,545\%) mengaku menggunakan Buku Iqra', hanya 4 (empat) responden yang menggunakan Buku Juz Amma, dan sisanya 2 (responden) menggunakan buku sekolah.

Dominasi penggunaan Buku Iqra' untuk belajar membaca Alquran di masyarakat lokasi penelitian berkaitan erat dengan penerapan metode belajar mengaji yang belakangan ini banyak digunakan masyarakat. Sebelummucul Buku Iqra', masyarakat di lokasi penelitian dalam masa yang cukup lama menggunakan Buku Juz Ammaa atau sering disebut "Qur'an Kecil' sebagai buku pegangan belajar mengaji anak-anak mereka. Dalam dua dasawarsa terakhir, Dominasi Buku Iqra' sebagai buku pegangan belajar mengaji menggeser dominasi penggunaan Juz Amma, walaupun sebagian masyarakat masih menggunakannya. Dominasi itu tampaknya mempengaruhi kemampuan membaca Alquran siswa seperti yang diinformasikan oleh hasil penelitian ini.

3. Metode belaj ar mengaj i

Ada tiga macam metode belajar membaca Alquran yang diikuti siswa yang diteliti ketika mereka belajar mengaji, yakni metode bagdadiyah, metode iqra', dan metode qir'ati. Hanya perbandingan banyaknya siswa yang menggunakan ketiga metode sangat jauh berbeda. Metode Iqra' diikuti oleh 104 responden (94,545\%), sedangkan dua metode lainnya yakni metode bagdadiyah diikuti oleh 5 (lima) responden dan metode qir'ati hanya diikuti satu responden.

Tampaknya persis sama jumlah responden yang mengikuti metode iqra' dengan responden yang menggunakan Buku Iqra' yaitu sebanyak 104 responden. Informasi ini menunjukkan betapa memasyarakatnya metode iqra' di lokasi penelitian. Menurut keterangan salah seorang petugas terkait di Kantor Departemen Agama Kabupaten Gowa bahwa penggvmaan metode Iqta' ualam be)ajar membaca Alquran di daerah ini cukup semarak, setidaknya dalam satu windu terakhir. Lembaga atau kelompok serta perorangan yang menyelenggarakan pengajaran membaca Alquran yang tersebar sampai pelosok pedesaan seperti TPA/TPQ, guru mengaji privat, dan perorangan, hampir semuanya menggunakan metode iqra'. Dominasi penggunaan metode iqra' yang demikian menonjol mempengaruhi kemampuan membaca Alquran siswa, sebagaimana terungkap lewat hasil penelitian ini. 


\section{Pat Badrun}

4. Motivasi belajar mengaji

Keinginan atau semangat untuk belajar membaca Alquran tidak timbul begitu saja melainkan didorong oleh motif-motif tertentu. Ketika kepada responden penelitian diajukan pertanyaan tentang motif atau alasan apa yang mendorong belajar membaca Alquran, kemudian disuruh memilih di antara lima jawaban yang disediakan, temyata 90 responden $(81,82 \%)$ yang memilih "karena dorongan kewajiban sebagai muslim", dan 17 responden $(15,45 \%)$ yang "kemauan sendiri". Sisanya, 2 (dua) responden beralasan "memenuhi keinginan orang tua" dan 1 (satu) responden yang menyatakan "untuk mendukung pelajaran terkait di sekolah". Dominasi yang memilih alasan "dorongan kewajiban sebagai muslim" tampaknya mempengaruhi kemampuan membaca Alquran siswa.

Melakukan kegiatan yang merupakan bagian dari kewajiban agama dengan atau atas dasar kesadaran sebagi umat beragama yang taat, memiliki nilai pengabdian yang tinggi dibandingkan dengan melakukannya karena dorongan-dorongan lain yang terkait dengan tujuan-tujuan tertentu. Namun bagi siswa yang diteliti, pilihan "karena dorongan kewajiban sebagai muslim" lebih bersifat penyesuaian diri dengan adanya ketentuan lain yang mengikat mereka, baik selaku warga masyarakat Kabupaten Gowa maupun sebagai siswa sekolah tempat mereka belajar. Ketentuan yang dimaksud ialah adanya Perda Kabupaten Gowa Nomor 03 Tahun 2007 yang mengharuskan setiap siswa SD dan SLTP "bebas buta aksara Alquran".

5. Kesempurnaan pengucapan

Masalah pengucapan sedikit banyak dapat mempengaruhi kemampuan seseorang membaca Alquran. Misalnya karena cacat pada alat-alat pengucapan sehingga kecenderungan telor, begitu pula karena sengau dan kesumbangan pengucapan lainnya, sehingga tidak dapat menyebut atau mengucapkan dengan sempurna bunyi huruf hijaiyah dan berbagai perubahannya dalam bentuk kata. Hasil penelitian menunjukkan bahwa responden yang menyatakan memiliki pengucapan yang sempurna (55 responden atau 50\%) hampir sama jumlahnya dengan responden yang menyatakan memiliki pengucapan yang kurang sempurna (53 responden atau $48,18 \%$ ). Sedangkan responden yang menyatakan memiliki pengucapan yang sangat sempurna sama jumlahnya dengan responden yang menyatakan memiliki pengucapan yang tidak sempurna yakni masing-masing 1 (satu) 
Pat Badrun

responden. Perbedaan yang sangat menonjol itu yang kemudian didukung oleh rata-rata skor yang juga berbeda mempengaruhi kemampuan membaca Alquran siswa, sebagaimana kesimpulan hasil uji hipotesis mengenai hal tersebut.

\section{P E N U T U P}

\section{A. Kesimpulan}

1. Kemampuan membaca Alquran siswa.

Hasil analisis deskriptif terhadap dua kelompok data diatas menunjukkan perbedaan. Di satu pihak menunjukkan'bahwa kemampuan umum membaca Alquran siswa bervariasi menurut kategori yang diberikan yakni sangat mampu, mampu, kurang mampu, dan tidak mampu walaupun lebih separuh berada pada kategori mampu. Sementara dilain pihak kemampuan khusus membaca Alquran siswa relatif homogen dan terpusat pada kategori mampu. Perbedaan tersebut mengindikasikan adanya perbedaan dalam proses pembelajaran membaca Alquran di sekolah dan di masyarakat. Para siswa menilai bahwa proses pembelajaran membaca Alquran di sekolah memiliki tingkat kesulitan yang lebih rendah dibandingkan dengan proses pembelajaran membaca Alquran di masyarakat.

Kemampuan membaca Alquran siswa yang diteliti pada umumnya baik, dimungkinkan oleh beberapa hal yang mendukung, antara lain:

a. Tradisi masyarakat setempat yang menganggap "tahu mengaji" itu sebagai salah satu keharusan adat, sehingga menjadikan sang anak "tahu mengaji" merupakan tanggung jawab dan kewajiban orang tua.

b. Penerapan dengan konsekwen Peraturan Daerah (Perda) Nomor 07 Tahun 2003 tentang "bebas buta aksara Alquran" di tingkat SD dan SLTP, terutama ketika siswa menghadapi ujian akhir SD dan Ujian atau tes masuk SLTP.

c. Adanya keseriusan dari para kepala sekolah bersama guru PAI yang kemudian memanfaatkan peluang "pengembangan diri" yang disediakan dalam kurikulum yang berlaku dengan mengadakan salah satu kegiatan ekstra kulikuler bidang keagamaan berupa "kultum" atau kuliah tujuh menit yang diikuti siswa semua jenjang 
dan kelas secara bergilir. Kegiatan ini "memaksa" siswa untuk mempersiapkan diri termasuk penguasaan kemampuan membaca Alquran.

2. Faktor-faktor yang mempengaruhi kemampuan membaca Alquran.

Dari 15 hal yang semula diduga sebagai faktor-faktor yang dapat mempengaruhi kemampuan membaca Alquran siswa, setelah dilakukan proses penelitian (termasuk uji hipotesis mengenai hal tersebut), ternyata hanya 5 (lima) hal yang terbukti, yaitu pendidikan siswa sebelum SMP, buku pegangan siswa belajar membaca Alquran, metode belajar membaca Alquran yang digunakan, motivasi belajar membaca Alquran dari siswa, dan keadaan pengucapan siswa dalam melafalkan huruf-huruf hijaiyah. Dari lima faktor itu, tiga faktor yang disebut pertama merupakan faktor eksternal, sedangkan dua faktor yang disebut berikutnya merupakan faktor internal.

B. Saran

Dengan mengacu kepada temuan-temuan penelitian tentang kemampuan membaca Alquran siswa SMP Negeri di Kabupaten Gowa, maka pada bagian ini dikemukakan beberapa saran sebagai berikut:

1. Hasil penelitian ini menginformasikan bahwa para siswa yang diteliti menilai proses dan strategi pembelajaran membaca Alquran di sekolah (dalam hal ini SMP dan SLTP lainnya) lebih rendah daripada proses dan strategi pembelajaran membaca Alquran di masyarakat. Karena itu, perlu dilakukan peninjauan dan/atau perbaikan terhadap strategi pembelajaran membaca Alquran di sekolah tingkat SLTP. Peninjauan terhadap strategi pembelajaran membaca Alquran setidaknya mencakup 4 (empat) aspek, yakni mated, metode, tujuan (kompetensi dasar dan/atau kompetensi isi), dan evaluasi. Hal ini perlu dilakukan antara lain untuk menjaga citra sekolah agar mampu menampilkan strategi pembelajaran membaca Alquran yang lebih baik dibandingkan dengan yang berlaku di masyarakat.

2. Agar pihak sekolah dapat mempertahankan dan/atau lebih menigkatkan upaya-upaya yang dapat mendukung peningkatan kemampuan membaca Alquran siswa, baik melalui penugasan kepada siswa maupun melalui kegiatan ekstra kulikuler. 
3. Dorongan dari orang tua serta kerjasama yang baik antara orang tua anak dan guru PAI sangat diperlukan untuk mendukung upaya peningkatan kemampuan membaca Alquran siswa, terutama sekali bagi siswa yang belum memiliki kemampuan dasar membaca Alquran sebelum masuk SLTP.

4. Salah satu faktor yang berpengaruh terhadap kemampuan membaca Alquran siswa adalah metode pembelajaran Alquran yang diterapkan, sebagaimana informasi yang diperoleh bahwa masyarakat pada umumnya lebih suka menerapkan metode Iqra'. Karena itu, disarankan kepada guru PAI untuk mengupayakan penerapan metode iqra' dalam proses pembelajaran membaca Alquran di sekolah. Mungkin diperlukan modifikasi misalnya melakukan penyesuaian dengan metode SAS (Struktural Analitik Sintetik) yang memang dirancang (oleh Departemen Agama) untuk kebutuhan memberikan bimbingan membaca Alquran siswa di sekolah. Tentu saja di perlukan lebih dahulu studi mendalam tentang kelebihan dan kekurangan setiap metode untuk kemudian mendesain modifikasi yang merupakan perpaduan harmonis antara keduanya, kemudian melakukan uji coba penerapannya. 
Pat Badrun

\section{DAFTAR PUSTAKA}

Abu Hamid. 1983. Sistem Pendidikan Madrasah dan Pesantren di Sulawesi Selatan Dalam Taufiq Abdullah (ED) Agama dan Perubahan Sosial. Cet. I. Jakarta. Rajawali.

Azza Azyumardi. 1999. Pendidikan Islam Tradisi dan Modernisasi Menuju Milenium Baru. Jakarta. Logos.

BPS Kabupaten Gowa Propinsi Sulawesi Selatan. 2006. Kabupaten Gowa Dalam Angka 2006. Gowa. Kerjasama BPS dan BAPPEDA Kabupaten Gowa.

Departemen Pendidikan dan Kebudayaan. 1995. Kamus Besar Bahasa Indonesia. Cet. IV. Jakarta. Balai Pustaka.

Fadhal AR Bafadal, dkk. 1993. Laporan Studi ExperimentasiMetode Baca Tulis Alquran pada Sekolah Dasar. Jakarta. Pusat Litbang Penda Badan Litbang Agama Departemen Agama.

Human A'sad. 1990. Buku Iqra' : Cara Cepat Belajar Membaca Alquran. Yoyakarta.AMM.

Human A'sad, dkk. 2001. Pedoman Pengelolaan, Pembinaan dan Pengembangan Membaca, Menulis dan Memahami Alquran, Balai Litbang (PTQ) Nasional. Yogyakarta. Team Tadarrus AMM.

Radjab, Abdullah. 2001. Penulisan Huruf-huruf Alquran dengan Sistim Matematik Sebagai Media Pembelajaran: Suatu Kajian Penulisan Sistematis. Maros.

Shihab, M. Quraish. 1416 H/1996 M. "Membumikan Alquran". Fungsi dan Penman Wahyu Dalam Kehidupan Masyarakat. Cet. XII. Bandung. Mizan.

Shihab, M. Quraish. 1417 H/1996 M. Wawancara Alquran Tafsir Mandlut7Atas Pelbagai Persoalan Umat. Cet. IV. Bandung. Mizan.

Sulthan Muhajirin. 1999. Buku Belajar Mengaji Al-Barqy, Secepat Kilat Penasuci. Surabaya.

Tim Peneliti Puslitbang Lektur Keagamaan. 2006. Laporan Penelitian Kemampuan Membaca dan Menulis Huruf Alquran pada Siswa SMA/SMK Tahun 2006. Jakarta. Puslitbang Lektur Keagamaan Badan Litbang dan Diklat Departemen Agama RI.

Tim Penyusun. 2006. Buku Panduan Mitotan Lokal Baca Tulis Alquran., Cet. I. Makassar. CV. Ummul Chair.

Tim Penyusun. 2004. Hasil Peniantauan dan Evaluasi Gerakan Pembelajaran Alquran (GPQ) Propinsi Sulawesi Selatan. 